\title{
MODULATORY EFFECT OF SODIUM NITROPRUSSIDE AND 8Br-cGMP ON MASTOPARAN-7 INDUCED CONTRACTION
}

\author{
MODULUJĄCY WPŁYW NITROPRUSYDKU SODU I 8BR-CGMP \\ NA REAKTYWNOŚĆ MIĘŚNIÓWKI INDUKOWANY MASTOPARANEM-7
}

\author{
${ }^{1}$ Department of Pediatrics, Hematology and Oncology \\ ${ }^{2}$ Department of Pharmacology and Therapeutics \\ Collegium Medicum in Bydgoszcz, Nicolaus Copernicus University in Toruń, Poland
}

\begin{abstract}
S u m m a r y
Introduction. Mastoparan-7 activates G-protein and stimulates apoptosis, but in smooth muscle cells leads to increase in perfusion pressure.

Main aim of this study was to evaluate the modulatory effect of $8 \mathrm{Br}$-cGMP and sodium nitroprusside on vascular smooth muscle contraction induced by direct stimulation of G-protein with mastoparan-7.

Material and methods. Experiments were performed on isolated and perfused tail artery of Wistar rats. Contraction force in our model was measured by increased level of perfusion pressure with a constant flow.

Res u l t s . Concentration-response curves obtained for mastoparan-7 presented an sigmoidal relation. In presence of SNP and 8Br-cGMP the significant and dose dependent leftward shift with significant reduction in maximal responses was present. Moreover, analyzing function of calcium stores the significant inhibition of influx from both, intra- and extracellular calcium stores was present.

Conclusion. Results of our experiments suggest that contraction induced by direct activation of G-protein with mastoparan-7 may by effectively inhibited in the presence of donors of nitric oxide such as sodium nitroprusside and in the presence of $8 \mathrm{Br}$-cGMP.
\end{abstract}

Mastoparan-7 jest aktywatorem białka G, stymulującym apoptozę. W mięśniach gładkich naczyń krwionośnych zwiększa kurczliwość.

C e l e $\mathrm{m}$ prowadzonego badania było określenie wpływu nitroprusydku sodowego oraz 8Br-cGMP na skurcz mięśni gładkich wywołany bezpośrednią stymulacją białka $\mathrm{G}$ przez mastoparan-7.

Materiał i metody. Badania przeprowadzono na izolowanych i perfundowanych tętnicach ogonowych szczurów szczepu Wistar. Wykładnikiem skurczu w układzie doświadczalnym były zmiany ciśnienia perfuzyjnego.

Wyniki. Krzywe zależności efektu od stężenia agonisty uzyskane dla mastoparanu-7 miały przebieg odpo- wiadający krzywej sigmoidalnej. W obecności nitroprusydku sodowego i 8Br-cGMP zaobserwowano istotne przesunięcie krzywych w stronę prawą, tj. w stronę wyższych stężeń agonisty $\mathrm{z}$ jednoczesną redukcja efektu maksymalnego. Oceniając efektywność skurczu wyzwalanego napływem wapnia z przestrzeni wewnątrzkomórkowej i zewnątrzkomórkowej, stwierdzono istotne zmniejszenie napływu jonów wapnia z obydwu wymienionych magazynów.

Wnioski. Wyniki przeprowadzonych doświadczeń sugerują, że skurcz wyzwolony przez bezpośrednią aktywację białka G przez mastoparam-7 może być skutecznie hamowany przez donory tlenku azotu, jak np. nitroprusydek sodowy a także w obecności 8Br-cGMP.

Key words: mastoparan-7, mastoapran-17, phospholipase C, G-protein, 8Br-cGMP, sodium nitroprusside Stowa kluczowe: mastoparan-7, mastoparan-17, fosfolipaza C, białko G, 8Br-cGMP, nitroprusydek sodowy 


\author{
Abbreviations \\ CRC, concentration response curve \\ $\mathrm{EC}_{50}$, half maximal effect concentration \\ $\mathrm{E}_{\max }$, maximal tissue response \\ mas-7, mastoparan-7 \\ PLC, phospholipase C
}

\section{INTRODUCTION}

Mastoparan-7 is a basic tetradecapeptide isolated from wasp venom. The mechanism of its action is related to activation of $\mathrm{G}$ protein. Mastoparan-7 catalyze guanosine 5'-dipho-sphate/guanosine 5'triphosphate (GDP/GTP) exchange, thus mastoparan-7 acts as activated $G$ protein-coupled receptors. The peptide has been shown to stimulate PLC in several cellular compartments like rat mast cells, rat hepatocytes, and human HL-60 leukaemia cells. In contrast, inhibition of PLC by mastoparan has been demonstrated in SH-SY5Y human neuro-blastoma cells and in human astrocytoma cells [1]. Nitric oxide is most powerful agent released from vascular endothelium responsible for vasorelaxation. 8Br-cGMP is synthetic compound, analog of second messenger of nitric oxide in vascular smooth muscle cells $[2,3,4]$.

Calcium ions play the council role in the cell life. Accordingly to pathological factors, $\mathrm{Ca}^{2+}$ concentration changes occur in the various cell compartments, which may induce apoptosis $[5,6,7]$.

Our previous studies confirmed in isolated resistant artery model that mastoparan-7 is able to increase the calcium load in smooth muscle cytoplasm by activation of calcium influx from intra and extracellular calcium stores $[8,9]$.

Main aim of this study was to evaluate the modulatory effect of 8Br-cGMP and sodium nitroprusside on vascular smooth muscle contraction induced by direct stimulation of G-protein with mastoparan-7.

\section{METHODS}

\section{Animals}

Experiments were performed on isolated and perfused tail artery of Wistar rats (weight $250 \mathrm{~g}$ to 270 g). Animals were housed under a $12 \mathrm{~h}$ light/12h dark cycle and had unlimited access to food and water. Rats were narcotized by intraperitoneal injection of $120 \mathrm{mg}$ urethane per $1 \mathrm{~kg}$. Rats were killed by stunnig and cervical dislocation. The study protocol was approved by the Local Ethics Committee. All studies were carried out in accordance with the United States NIH guidelines [Guide for the Care and Use of Laboratory Animals (1985), DHEW Publication No. (NIH) 85-23: Office of Science and Health Reports, DRR/NIH, Bethesda, MD, U.S.A.].

\section{Drugs and solutions}

Mastoparan-7 (G-protein activator), Mastoparan-17 (negative control). Krebs solution contained $\mathrm{NaCl}$ (71.8 mM/l), $\mathrm{KCl}(4.7 \mathrm{mM} / \mathrm{l}), \mathrm{CaCl}_{2}(1.7 \mathrm{mM} / \mathrm{l})$ $\mathrm{NaHCO}_{3}(28.4 \mathrm{mM} / \mathrm{l}), \mathrm{MgSO}_{4}(2.4 \mathrm{mM} / \mathrm{l}), \mathrm{KH}_{2} \mathrm{PO}_{4}$ $(1.2 \mathrm{mM} / \mathrm{l})$ and glucose $(11.1 \mathrm{mM} / \mathrm{l})$. All reagents were purchased from Sigma Aldrich Chemical Co.

\section{Study design and conduction}

After dissection from surrounding tissues, $2-3 \mathrm{~cm}$ long segment of a rat tail artery was cannulated and connected to a perfusion device. The distal part was weighted with $500 \mathrm{mg}$ weight and the tail was placed in a $20-\mathrm{mL}$ container filled with oxygenated Krebs solution at $37^{\circ} \mathrm{C}(\mathrm{pH} \mathrm{7,4)}$. The perfusion pressure was continuously measured. We gradually increased perfusion solution flow using a peristaltic pump to $1 \mathrm{~mL} / \mathrm{min}$, until the optimum perfusion pressure $2-4 \mathrm{kPa}$ [10].

\section{Data analysis and statistical procedures}

Investigations were performed on TSZ-04 system, Experimetria Ltd. Budapest. Perfusion pressure was measured on BPR-01 and BPR-02 devices, vascular smooth muscle tension was measured on FSG-01 transducer connected with digital recorder Graphtec midi Logger GL820. All transducers used in our experiments were made by Experimetria Ltd, Budapest. Peristaltic pump was made by ZALIMP.Concentration-response curves (CRCs) were calculated according to the van Rossum method. Maximum response of tissue (Emax) was calculated as a percent of maximal response for phenylephrine. Half maximal effective concentration $\left(\mathrm{EC}_{50}\right)$ was estimated using classical pharmacologic methods with $\mathrm{pD} 2$ the negative logarithm of the EC 50. We used the number of the CRC and Emax in all calculations estimating the statistical significance. As negative control mastoparan-17 has been used.

Results are presented as mean values \pm standard deviation. Statistical analysis was performed using the ANOVA test for multiple comparison of means. 
Values of $\mathrm{p}$ below 0.05 were considered statistically significant.

\section{RESULTS}

Concentration-response curve obtained for mastoparan-7 presented a sigmoidal relation. In presence of SNP and $8 \mathrm{Br}$-cGMP the significant leftward shift with significant reduction in maximal responses was present. This effect was dose dependent (Figure 1 and 2). For all points for effect $20 \%$ or more the differences were statistically significant. Calculated $\mathrm{E}_{\text {max }}, \mathrm{EC}_{50}$ and $\mathrm{pD}_{2}$ values were presented in Table 1.

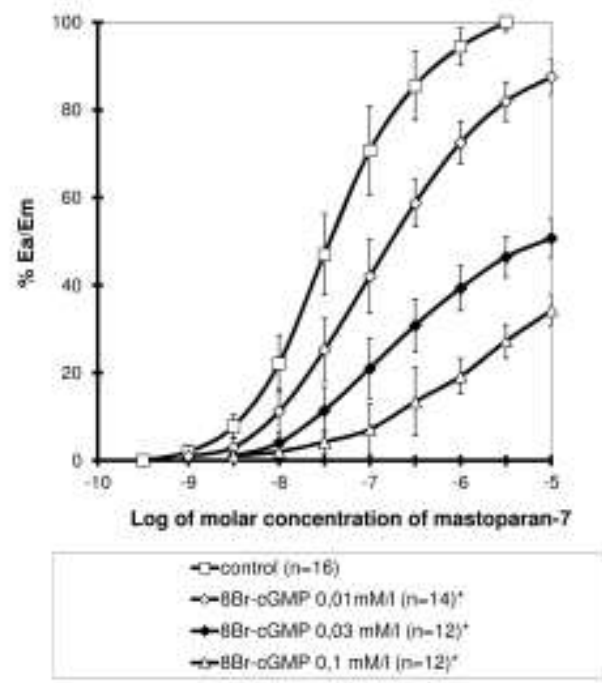

Fig. 1. Concentration response curves for mastoparan-7 in the control and in the presence of sodium nitroprusside

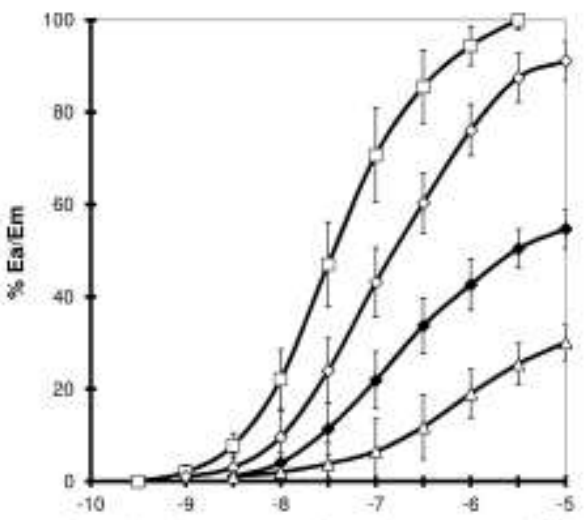

Log of molar concentration of mastoparan-7 [M/]

$$
\begin{aligned}
& \text { - }- \text {-kentrola }(n-16) \quad \quad \text {-SNP } 0.01 \text { mMn }(n-16)^{*} \\
& \text {-SNP D.03 mMa }(n=16)^{\circ} \quad \text { - } \quad \text { SNP } 0.1 \mathrm{mMM}(\mathrm{n}=16)^{\circ}
\end{aligned}
$$

Fig. 2. Concentration response curves for mastoparan-7 in the control and in the presence of $8 \mathrm{Br}-c \mathrm{GMP}$
Table 1. EC $C_{50}$, maximal response and relative potency for mastoparan-7 for controls and in the presence of

\begin{tabular}{|c|c|c|c|c|c|c|}
\hline & $n^{1}$ & $\% \mathrm{E}_{\max }^{2}$ & $\mathrm{EC}_{50}[\mathrm{M} / \mathrm{I}]$ & $\mathrm{pD}_{2}$ & \begin{tabular}{|l|}
$\mathbf{R P}^{3}$ \\
\end{tabular} & p \\
\hline control & 16 & 100 & $\begin{array}{c}4.41( \pm 2.33) \\
\times 10^{-8}\end{array}$ & $7.40 \pm 0.20$ & 1.000 & - \\
\hline $\begin{array}{l}\text { SNP } \\
\quad 0.01 \mathrm{mM} / \mathrm{l}\end{array}$ & 16 & $91 \pm 9$ & $\begin{array}{c}2.26( \pm 0.58) \\
\times 10^{-7}\end{array}$ & $6.66 \pm 0.13$ & 0.195 & $<0.0001$ \\
\hline $\begin{array}{l}\text { SNP } \\
\quad 0.03 \mathrm{mM} / \mathrm{l}\end{array}$ & 16 & $55 \pm 8$ & $\begin{array}{c}3.13( \pm 0.73) \\
\times 10^{-7}\end{array}$ & $6.51 \pm 0.09$ & 0.141 & $<0.0001$ \\
\hline $\begin{array}{l}\mathrm{SNP} \\
\quad 0.1 \mathrm{mM} / \mathrm{l}\end{array}$ & 16 & $30 \pm 6$ & $\begin{array}{c}7,51( \pm 0,32) \\
\times 10^{-7}\end{array}$ & $6.12 \pm 0.20$ & 0.059 & $<0.0001$ \\
\hline $\begin{array}{l}\text { 8Br-cGMP } \\
0.01 \mathrm{mM} / 1\end{array}$ & 14 & $88 \pm 11$ & $\begin{array}{c}1,61( \pm 0,79) \\
\times 10-7\end{array}$ & $6.84 \pm 0.20$ & 0.274 & $<0.0001$ \\
\hline $\begin{array}{l}\text { 8Br-cGMP } \\
0.03 \mathrm{mM} / \mathrm{l}\end{array}$ & 12 & $51 \pm 8$ & $\begin{array}{c}2,89( \pm 0,84) \\
\times 10-7\end{array}$ & $6.56 \pm 0.13$ & 0.153 & $<0.0001$ \\
\hline $\begin{array}{c}\text { 8Br-cGMP } \\
0.1 \mathrm{mM} / 1\end{array}$ & 12 & $34 \pm 8$ & $\begin{array}{c}7,15( \pm 0,82) \\
\times 10-7\end{array}$ & $6.15 \pm 0.05$ & 0.062 & $<0.0001$ \\
\hline
\end{tabular}
sodium nitroprusside (PTX) and $8 B r-c G M P$

${ }^{1}$ - number of concentration-response curves used for calculations, ${ }^{2}-$ Emax - calculated as a percent of maximal response for controls, ${ }^{3}-$ $\mathrm{RP}$ - relative potency - calculated as $\mathrm{EC}_{50}$ for controls / $\mathrm{EC}_{50},{ }^{4}$ - pvalue calculated in comparison to control values

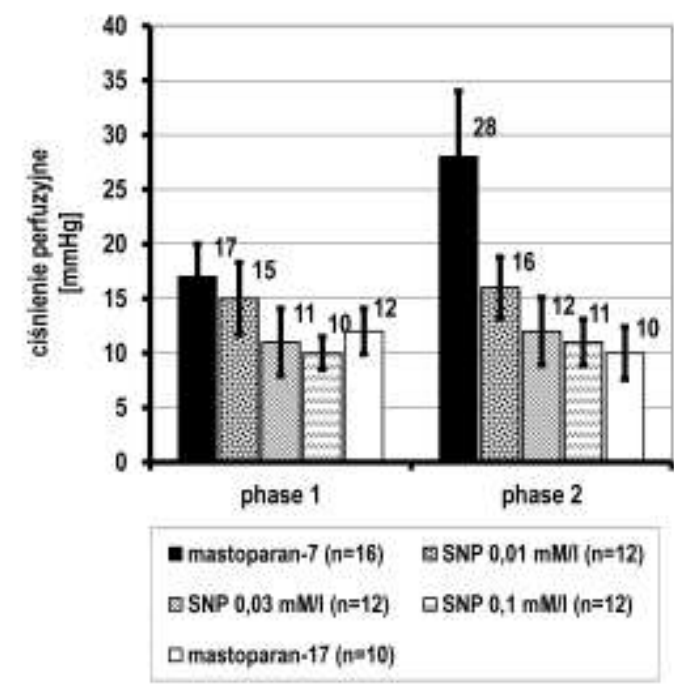

Fig. 3. Impact of G-protein activation by mastoparan 7, on perfusion pressure triggered with intra- and extracellular calcium pool in comparison to the control (mastoparan 17) and in the presence of sodium nitroprusside (SNP)

Analyzing the perfusion pressure as a result of intracellular calcium influx for mastoparan-7 the significant increase was observed in comparison to negative control - mastoparan-17. The same relation was observed after extracellular calcium influx to 
cytoplasm. In comparison to phenylephrine and vasopressin all values of perfusion pressure after stimulation of G-protein by mastoparan-7 were significantly lower (Figure 3 and 4).

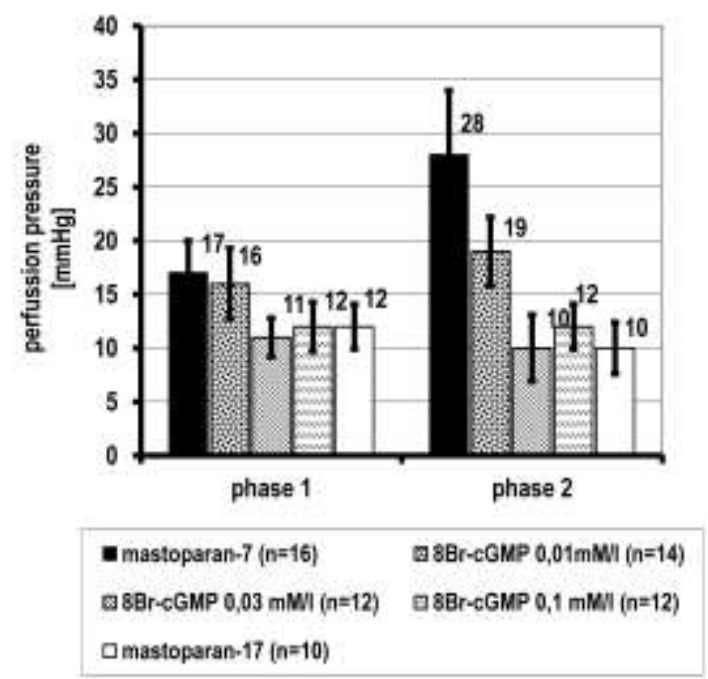

Fig. 4. Impact of G-protein activation by mastoparan 7, on perfusion pressure triggered with intra- and extracellular calcium pool in comparison to the control (mastoparan 17) and in the presence of $8 \mathrm{Br}$ $c G M P$

\section{DISCUSSION}

In performed experiment, vessel contraction was induced with mastoparan-7, an activator of G-protein. Kanagy et al. [11], investigated spiral cutting fragments of common carotid artery and showed measureable response after 10 minutes, and maximum response after 30 minutes from application of mastoparan-7 (10 $\left.0^{-5} \mathrm{M} / \mathrm{L}\right)$ [12]. Moreover, in rats with hypertension, arteries reactivity was significantly higher than controls. Nifedpine in the concentration of $10^{-5} \mathrm{M} / \mathrm{L}$, inhibits contraction of VSMC by mastoparan-7 in concentration $10^{-7} \mathrm{M} / \mathrm{L}$. This relationship reveals correlation between voltagedependent calcium channels and vasoconstriction induced by mastoparan-7. The lack of complete reversal by nifedipine at higher concentrations of mastoparan $\left(10^{-5} \mathrm{M} / \mathrm{L}\right)$ suggests that an additional mechanism is activated at this higher concentration [7, 11].

In our study impact of donor of nitric oxide sodium nitroprusiide and its second messenger 8Br-cGMP on mastoparan7-induced contraction has been observed. We found a significant inhibition of contraction, triggered by G-protein activation, and proportional perfusion pressure reduction caused by intra- and extracellular calcium influx in the presence of both modulating agents.

Mastoparan-7 penetrates via biological barriers, and binds to G-protein binding site ligand-receptor. It stimulates G-protein in analogical way as activating receptor. Evaluated in biochemical studies, mastoparan's affinity to individual types of $G$ protein is significantly different. Mastoporan-7 shows higher affinity to $G_{i}$ and $G_{O}$ proteins, than $G_{S}$ protein [13] Perianin et al. demonstrated, that mastoparan-7 can increase calcium ions concentration in cytoplasm through the mechanisms which are unrelated with $\mathrm{IP}_{3}$ and DAG production [14].

Affinity to $\mathrm{G}_{\mathrm{q}}$-protein has not been specified so far, however there were performed functional investigations over the process of activation G-protein with mastoparan-7 in vascular smooth muscle cells of carotid artery in rats. The results showed that mastoparan-7 activates $\mathrm{G}_{\mathrm{q}}$-proteins in vascular smooth muscle cells, and secondarily to the increase of calcium ions concentration in cytoplasm, vasoconstriction has been observed. Moreover, in rats with genetically determined hypertension, contraction of vascular smooth muscle cells was significantly higher, than control group [11]. Mastoparan-7 may activate phospolipase $A_{2}$ in concentration of $5 \times 10^{-5} \mathrm{M} / \mathrm{L}$, leads to degranulation of mast cells [15]. In vascular smooth muscle cells, processes of prostanoids production do not modify contraction triggered by mastoparan-7, it is confirmed by experiments performed in the presence of indomethacin. In these studies the significant impact of indomethacin has not been observed. Mastoparan-7 in the concentration $10^{-5} \mathrm{M} / \mathrm{L}$, may impact on vasoconstriction also by additional mechanisms such as calcium channels modulation and voltageindependent calcium channels [14]. Mastoparan-7 demonstrates also direct action on PLC. In low concentration $\left(<3 \times 10^{-6} \mathrm{M} / \mathrm{L}\right)$ PLC activation has been inhibited by mastoparan-7, but in higher concentration ( $>5 \times 10^{-6} \mathrm{M} / \mathrm{L}$ ) direct activation has been found [16, 17]. In our current and previous studies lower concentration of mastoparan-7 (3 x $10^{-10}-3 \times 10^{-}$ ${ }^{6} \mathrm{M} / \mathrm{L}$ ) has been used [8, 9]. In view of this fact, used concentrations were not high enough to change other, than G-protein elements of signaling pathway. Vasoconstriction induced by mastoparan-7, depends on intra- and extracellular calcium pool, which also may affect apoptosis. The effect of this process was higher values of perfusion pressure. 
The constriction of VSMC obtained by mastoparan7 was significantly lower in comparison to phenylephrine and vasopressin. It was confirmed by Kanagy et al. [11]. The effects observed for mastoparan-7 was similar to the effect occurred after activation by partial agonist, in distinction to full agonist such as phenylephrine or vasopressin. Related perfusion pressure values induced by clonidine $\alpha_{2}$-receptor agonist moreover inhibitory effect of SNP and $8 \mathrm{Br}-\mathrm{cGMP}$ was similar to observed during stimulation of G-protein coupled receptors [4].

\section{CONCLUSIONS}

Results of our experiments suggest that contraction induced by direct activation of G-protein with mastoparan-7 may by effectively inhibited in the presence of donors of nitric oxide such as sodium nitroprusside and in the presence of $8 \mathrm{Br}$-cGMP.

\section{REFERENCES}

1. Kling, T. P., et al.: Inflammatory Role of Two Venom Components of Yellow Jackets (Vespula vulgaris):A Mast Cell Degranulating Peptide Mastoparan and Phospholipase A1. Int. Arch. Allergy Immunol. 2003; 131: 25-32.

2. Vane J. R., Gryglewski R. J., Botting R. M.: The endothelial cells as a metabolic and endocrine organ. Trends Pharmacol. Sci., 1987; 8: 491-496.

3. Vanhoutte P. M., Verbeuren T. J., Webb R. C.: Local modulation of adrenergic neuroeffector interaction in the blood vessel wall. Physiol. Rev., 1981; 61: 151 - 247.

4. Grześk G, Szadujkis-Szadurski L.: Modyfikacja reaktywności receptorów $\alpha$-adrenergicznych przez $8 \mathrm{Br}$ cGMP i angiotensynę II. Ann. Acad. Med. Bydg. 2003; 17/3: 5-10.

5. Hajnoczky G, Davies E, Madesh M.: calcium signaling and apoptosis. Biochem Biophys Res Commun 2003; 304: 445-454.

6. Newmeyer DD, Ferguson-Miller S.:Mitochondria: Releasing power for life and unleashing the machineries of death. Cell 2003; 112: 481-390.

7. Grześk G, Wiciński M, Malinowski B et al: Calcium blockers inhibits cyclosporine A-induced hyperreactivity of vascular smooth muscle cells. Mol Med Report. 2012; 5:1468-1474.

8. Grześk G, Malinowski B, Grześk E, et al.: Direct regulation of vascular smooth muscle contraction by mastoparan-7. Biomed Rep. 2014;2:34-38.
9. Grześk E, Tejza B, Wiciński Met al.: Effect of pertussis toxin on calcium influx in three contraction models. Biomed Rep. 2014;2:584-588.

10. Grześk G, Szadujkis-Szadurski L: Physiological antagonism of angiotensin II and lipopolysaccharides in early endotoxemia: pharmacometric analysis. Pol J Pharmacol. 2003; 55: 753-762.

11. Kanagy NL, Webb RC: Enhanced vascular reactivity to mastoparan, a G protein activator, in genetically hypertensive rats. Hypertension. 1994; 23; 946-950.

12. Birnbaumer L.: The discovery of signal transduction by G-proteins. A personal account and anoverview of the initial findings and contributions that led to our present understanding. Biochim Biophys Acta. 2007; 1768; 756771.

13. Higashijima T, Burnier J, Ross EM.: Regulation of Gi and Go by mastoparan, related amphiphilic peptides, and hydrophobic amines. Mechanism and structural determinants of activity. J Biol Chem.1990; 265: 1417614186.

14. Perianin A, Synderman R.: Mastoparan, a wasp venom peptide, indentifies two discrete mechanisms of elevating cytosolic calcium and inositol triphosphates in human polymorphonuclear leukocytes. J Immunol. 1989; 143 : 1669-1673.

15. Argiolas A, Pisano JJ.: facilitation of phospholipase $A_{2}$ activity by mastoparan, a new class of mast cell degranulating peptides from wasp venom. J Biol Chem. 1983; 258: 13697-13702.

16. Wallace MA, Carter HR.: effects of the wasp venom peptide, mastoparan, on a phosphoinositide-specific phospholipase $\mathrm{C}$ purified from rabbit brain membranes. Biochim Biophys Acta. 1989; 1006: 311-316.

17. Hiramatsu $\mathrm{T}$, Sonoda $\mathrm{H}$, Takanezawa $\mathrm{Y}$, et al.: Biochemical and molecular characterization of two phosphatidic acid-selective phospholipase A1s, mPAPLA1alpha and mPA-PLA1beta. J Biol Chem. 2003; 278:49438-47.

Address for correspondence:

Elżbieta Grześk, MD, PhD

Department of Pediatrics, Hematology and Oncology

Collegium Medicum, Nicolaus Copernicus University

Skłodowskiej-Curie 9

85-094 Bydgoszcz, Poland

e-mail: ellag@cm.umk.pl

Received: 13.10 .2014

Accepted for publication: 17.11.2014 